\title{
Psihološki vidiki medvrstniškega nasilja v šolah: ugotovitve nekaterih slovenskih raziskav
}

\author{
Sonja Pečjak in Tina Pirc
}

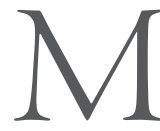

edvrstniško nasilje (v nadaljevanju: MVN) se pojavlja na vseh šolah, pri čemer se nekatere šole s tem problemom ukvarjajo odprto in pošteno (Sullivan, 20II), druge pa pojave MVN prikrivajo, »pometajo pod preprogo « in se $\mathrm{z}$ njim ukvarjajo le v primerih, ko to izbruhne - praviloma v intenzivni obliki s hudimi posledicami za žrtev/-ve - ter to pride v medije, največkrat zaradi staršev.

Psihološka stroka je pričela sistematično preučevati MVN relativno pozno - v 70 -ih letih preteklega stoletja. Med prvimi raziskovalci tega pojava je bil norveški raziskovalec Olweus (1973 in 1978), ki se je lotil preučevanja razširjenosti posameznih oblik MVN pri učencih osnovne in srednje šole. Pobuda za to je prišla s strani norveškega ministrstva za šolstvo kot reakcija na samomore treh norveških osnovnošolcev, ki so bili posledica MVN. Pri nas sta s preučevanjem MVN v 9o-ih letih pričela Bojan Dekleva (1996) z Instituta za kriminologijo Pravne fakultete in Mojca Pušnik (1999) z Zavoda za šolstvo.

Za predstavljena poglavja $v$ nadaljevanju smo se odločili iz različnih razlogov. V prvem poglavju smo želeli čim bolj jasno (enoznačno) opredeliti pojav MVN, kajti samo tako lahko vsebinsko veljavno raziskujemo ta pojav. Podpoglavje o razširjenosti MVN smo vključili, ker med učitelji, starši in laično javnostjo pogosto naletimo na izjave, da je tega nasilja med mladimi vedno več. Skušali smo pokazati, da je to tezo iz različnih razlogov empirično raziskovalno težko potrditi oz. ovreči. Nadalje obravnavamo aktualne pojave, $\mathrm{s}$ katerimi se $\mathrm{v}$ slovenskem prostoru srečujemo danes in so pogosto povezani z MVN - kot je npr. fazaniranje -, pišemo o dolgo 
spregledani skupini opazovalcev in njihovi vlogi pri MVN ter izpostavljamo vlogo šolske kulture pri spoprijemanju z MVN na šolah.

\section{Nekatere dileme, povezane z medvrstniškim nasiljem v šolah}

\section{Kdaj gre za medvrstniško nasilje in kdaj ne?}

Kdaj govorimo o MVN v šoli? Med prvimi in najpogosteje navedenimi opredelitvami MVN je Olweusova definicija (1993), ki pravi, da o tem nasilju lahko govorimo, kadar je nek učenec v daljšem časovnem obdobju večkrat izpostavljen agresivnemu vedenju oz. negativnim dejanjem, ki jih je povzročil njegov vrstnik oz. skupina vrstnikov. Drugi avtorji (Smith, Ananiadou in Cowie, 2003; Sullivan, 20II) dodajajo tej definiciji še nekatere elemente: agresivno in/ali manipulativno in/ali izključevalno vedenje ene ali več oseb proti eni ali več (drugim) osebam je zavestno, namerno in ponavljajoče se ter vključuje neravnovesje moči med nasilnežem in žrtvijo (to neravnovesje je lahko fizično, psihično ali socialno).

Ta konceptualna opredelitev je pomembna za to, da lahko strokovni delavci šole (učitelji, svetovalni delavci), pa tudi učenci in starši vedo, kdaj govorimo o MVN in kdaj ne. Vsako neželeno vedenje namreč še ni MVN. Primer neželenih/nesprejemljivih vedenj v šoli so npr. grobe igre med učenci, ki vključujejo borbo (različne fantovske igre) ali draženje drugih učencev $z$ različnimi imeni. Vendar v primeru, da gre za enako kompetentne učence (v smislu, da med njimi ni neravnovesja moči), da to vedenje ni ponavljajoče in da ne želijo namerno povzročiti škode drugemu, tega ne moremo obravnavati kot MVN. Tudi različni ekscesi in disciplinski prekrški, npr. enkratni agresivni napad, ustrahovanje, nadlegovanje, ki je lahko za žrtev boleče in travmatično, ne sodijo med MVN. Pri tem pa je treba $\mathrm{v}$ vsakem primeru zaustaviti takšno vedenje in se pogovoriti z vpletenimi. Po drugi strani pa nekatera agresivna vedenja učencev zaradi intenzivnosti in resnosti posledic presegajo okvire MVN - npr. napadi drugih učencev z orožjem ali s kakšnim nevarnim predmetom, večje kraje, grožnje s povzročitvijo hudih telesnih poškodb ali smrti ter spolno nasilje. V teh primerih gre za kriminalna dejanja, ki niso več samo v pristojnosti šole, ampak jih morajo obravnavati zunanje institucije (policija in sodišče).

\section{Kakšna je razširjenost medvrstniškega nasilja?}

Zaradi več razlogov je težko narediti analizo razširjenosti MVN tako v posameznih obdobjih znotraj iste države kot tudi primerjavo o razširjenosti tega nasilja med različnimi državami. Prvič, raziskovalci uporabljajo za odkrivanje tega pojava različne instrumente. Nekateri od njih 
obravnavajo MVN kot enovit konstrukt in ugotavljajo samo vloge, ki jih imajo učenci v tem nasilju (žrtev, nasilnež, sočasna vloga žrtev-nasilnež), drugi ugotavljajo vloge učencev v različnih pojavnih oblikah nasilja - pri fizičnem, odnosnem in verbalnem nasilju, v zadnjih dvajsetih letih tudi pri spletnem nasilju. Drugič, načini zbiranja podatkov v raziskavah so različni - največkrat raziskovalci uporabljajo vprašalnike, na katere odgovarjajo učenci sami ali o učencih poročajo učitelji, redkeje pa so v uporabi druge raziskovalne tehnike - npr. intervjuji z učenci, poročanje vrstnikov in opazovanje učencev s strani raziskovalcev. Pri tem nekateri raziskovalci (npr. Sanders in Phye, 2004) opozarjajo, da je najbolj zanesljiva mera poročanja o učencih-nasilnežih nominacija s strani vrstnikov, nominacija učencev-žrtev pa enako zanesljiva kot samoporočanje. Tretjič, primerjavo med ugotovitvami raziskav otežujejo tudi relativno ohlapni kriteriji opredeljevanja MVN. Vprašanje je, kako vprašani razumejo, kaj pomeni »v daljšem časovnem obdobju ... večkrat izpostavljen«. Tako nekateri vprašalniki sprašujejo učence, naj pomislijo, kolikokrat so bili izpostavljeni posameznim vrstam MVN v zadnjem letu (Doupona Horvat, 20ı I; Doupona, 2016), v zadnjih šestih mesecih (Cheng et al., 2011; Jakin, 2013), v zadnjih dveh mesecih (Solberg in Olweus, 2003; Sapouna, 2008; Totura et al., 2009), nekateri pa celo kolikokrat v zadnjem mesecu (Cornell, 2012; Pečjak in Pirc, 2017). Zato seveda ti podatki niso neposredno primerljivi med seboj, kar pa poročevalci (raziskovalci in odločevalci) velikokrat spregledajo. Če obstajajo razlike v opredeljevanju »daljšega časovnega obdobja«, pa so raziskovalci dokaj skladni v kriteriju, kdaj lahko govorimo o določeni vlogi učenca pri MVN - o posamezni vlogi učenca v MVN (̌̌rrtev, nasilnež, nasilnež-žrtev) govorimo takrat, kadar se to nasilje pojavlja pri učencu vsaj dva- do trikrat na mesec.

\section{Ugotovitve raziskav o razširjenosti medvrstniškega nasilja}

Pregled raziskav iz različnih kulturnih okolij pa vseeno kaže določene splošne oz. skupne značilnosti tega pojava.

Prvič, med mlajšrimi učenci v osnovni šoli je več MVN kot med starejšimi osnovnošolci in srednješolci (Benitez in Justicia, 2006; Olweus, 1995; Pellegrini, 2002). MVN naj bi svoj vrh doseglo v obdobju poznega otroštva in zgodnjega mladostništva, potem pa postopno upada (Gofin, Palti in Gordon, 2002; Nansel et al., 2002). Porast MVN raziskovalci pojasnjujejo predvsem s spremembami v socialni hierarhiji pri otrocih/mladostnikih v tem obdobju, ko si poskušajo na različne načine zagotoviti čim boljši položaj v vrstniški skupini, ki jim v tem obdobju postane zelo pomembna. $V$ tem času učenci preidejo tudi iz nižje na višjo stopnjo izobraževanja z nekoliko drugačno šolsko kulturo - v večje razrede z manj osebnimi 
odnosi (Simmons in Blyth, 1987) in z večjim stresom zaradi tekmovalnosti in socialne primerjave med vrstniki (Eccles, Wigfield in Schiefle, 1998), kar lahko privede do porasta MVN. Upad MVN v obdobju srednjega in poznega mladostništva pa raziskovalci največkrat povezujejo z večjo socialno zrelostjo in kompetentnostjo mladostnikov, ki jim omogoča, da se z različnimi problemskimi situacijami v odnosu z vrstniki spoprijemajo na bolj prilagojen način.

Drugič, $v M V N$ je udeleženih več fantov kot deklet. Pri tem se fantje pogosteje kot dekleta pojavljajo $\mathrm{v}$ vseh vlogah - v vlogi nasilnežev, žrtev in v dvojni vlogi nasilnežev-žrtev (Doupona, 20ı6; Marsh et al., 20Ir; Olweus, 1993; O'Neill, 2008). Obstajajo pa razlike med spoloma - fantje so pogosteje udeleženi v fizičnem nasilju, in sicer kot nasilneži in žrtve (Olweus, 1993; Polak, Smrtnik Vitulić in Vošnjak, 2011), dekleta pa pri odnosnem nasilju. Razloge za to gre verjetno iskati v procesih socializacije. Pri dojenčkih in malčkih namreč glede na spol niso ugotovili pomembnih razlik $\mathrm{v}$ agresivnosti, te pa se pojavljajo od predšolskega obdobja dalje. $\mathrm{Za}$ fante so bolj značilne - in sprejemljive - oblike fizične agresivnosti (npr. pretepi), kar se za dekleta ne spodobi. Pri dekletih pa se dopuščajo verbalne in odnosne oblike agresivnosti, npr. socialna izolacija, opravljanje (Archer in Coyne, 2005; Besag, 2006; Carpenter in Ferguson, 2009; Seals in Young, 2003; Smith, Madsen in Moody, 1999). Zato ni presenetljivo, da število fantov-nasilnežev ostaja skozi leta relativno enako, medtem ko število deklet-nasilnic s starostjo pomembno upada. To kaže na povezanost MVN s socializacijskimi procesi pri fantih in dekletih ter na povezavo $s$ praviloma večjo tolerantnostjo okolja do bolj aktivnega/impulzivnega vedenja fantov (Marsh et al., 2011; Olweus, 1995).

Tretjič, vloge $v M V N$ so relativno stabilne, še zlasti vloga nasilneža, manj vloga žrtve in najmanj vloga opazovalca/ev (Schäfer et al., 2005; Smith et al., 2004a). To kaže, da je treba veliko strokovnega dela s posameznimi skupinami učencev na šoli (delo učiteljev, svetovalnih delavcev), da se posamezni učenec $\gg$ reši svoje vloge.

Še najbolj objektivne primerjave med državami nudijo različne mednarodne raziskave, ki zajamejo tudi problematiko MVN. Take so npr. raziskave Svetovne zdravstvene organizacije (WHO), ki med številnimi podatki pri Is-letnikih ugotavljajo tudi stopnjo prisotnosti MVN. Podatki primerjalne analize WHO za leto 2004 so pokazali, da je Slovenija med 39 sodelujočimi državami med sedmimi državami z najmanjšo stopnjo MVN - skupaj s Švedsko in Finsko, Madžarsko, Italijo, Češko in Malto (pri nas je $17 \%$ učencev poročalo, da so bili žrtve MVN; WHO, 2004). Taista raziskava je ugotavljala tudi dinamiko MVN v šolah med II. in I5. letom glede na zastopanost posameznih vlog. $\mathrm{V}$ povprečju lahko pri 
državah, ki so sodelovale v raziskavi, ugotovimo nek robusten trend, da $s$ starostjo upada število žrtev, nekoliko pa se poveča število nasilnežev in da je pri starosti I in in let prisotnega več MVN kot pri starosti is let. Pri nas se kaže, da imamo pri ı-letnikih bistveno manj nasilnežev in žrtev, kot je povprečje v drugih državah; število nasilnežev in žrtev pa se pri rz-letnikih dvigne na raven povprečja drugih držav in ostane enako tudi še pri Is-letnikih. Dobljeni rezultati v Sloveniji navajajo na tezo, da se s problematiko MVN verjetno več ukvarjajo v nižjih razredih osnovne šole in da bi bilo treba v zvezi s tem več narediti zlasti v višjih razredih osnovne šole.

Primerljive rezultate o razširjenosti MVN, kot o njih poroča $\mathrm{WHO}$, najdemo tudi v poročilu UNICEF-a (2014). Zbrani podatki iz $106 \mathrm{dr}$ žav kažejo pri mladostnikih med I3. in I5. letom veliko variabilnost pri MVN: od 7 \% v Tadžikistanu do $74 \%$ mladostnikov na Samoi poroča, da so bili nedavno žrtev MVN. Podobno oceno daje tudi poročilo organizacije UNESCO (2017) - 38 \% učencev iz manj razvitih držav v starosti III3 let poroča, da so bili v preteklih mesecih žrtve MVN, od tega jih je bilo $8 \%$ dnevno trpinčenih.

Tudi mednarodna raziskava bralne pismenosti PIRLS 20 I je pri učencih 4. razreda ugotavljala prisotnost MVN v šoli in pokazala, da je bilo v Sloveniji približno $32 \%$ učencev žrtev MVN mesečno in I 8 \% takih, ki so bili žrtve tedensko (Doupona Horvat, 20II). V študiji PIRLS iz leta 2015 pa so ugotovili, da je bilo žrtev MVN Is \% na teden (Doupona, 20I6). Pri tem je bilo med otroki, ki so bili tedensko izpostavljeni MVN, približno dve tretjini fantov.

Iz raziskav izhaja, da so nekateri učenci žrtve/nasilneži le občasno, nekateri pa se znajdejo v teh vlogah pogosto. Zato sva S. Pečjak in T. Pirc (20I7) na vzorcu 4I 4 učencev osnovne in srednje šole ugotavljali pogostost vključenosti učencev v MVN glede na stopnjo šolanja, starost (učenci in dijaki v zgodnjem, srednjem ali poznem obdobju mladostništva), spol in učno uspešnost. Pri tem sva učence glede na pogostost izpostavljenosti MVN razdelili v tri kategorije: nežrtve in nenasilneži (niso imeli izkušnje MVN v zadnjem mesecu), občasne žrtve/nasilneži (vključeni v MVN enkrat do trikrat na mesec) in kronične žrtve/nasilneži (vključeni v MVN enkrat na teden ali večkrat). Dobljeni rezultati so prikazani v Tabeli I.

Rezultati naše študije $\mathrm{v}$ splošnem potrjujejo ugotovitve tujih raziskav, saj kažejo na pomembne razlike med žrtvami glede na stopnjo šolanja in starost. Med kroničnimi in občasnimi žrtvami je pomembno več osnovnošolcev (mlajših mladostnikov) kot srednješolcev (starejših mladostnikov). $\mathrm{V}$ vlogi žrtve (občasne in kronične) se pomembno pogosteje kot fantje znajdejo dekleta, v vlogi nasilnežev (občasnih in kroničnih) pa učno manj uspešni učenci. Empirični rezultati tudi kažejo, da se število 
Tabela I: Razlike med skupinami žrtev in nasilnežev glede na izbrane socioekonomske značilnosti učencev.

\begin{tabular}{|c|c|c|c|c|c|}
\hline \multicolumn{2}{|c|}{ 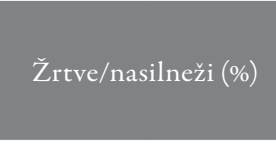 } & $\begin{array}{c}\text { Ne-žrtve/ } \\
\text { Ne-nasilneži }\end{array}$ & $\begin{array}{c}\text { Občasne } \\
\text { žrtve/ } \\
\text { Občasni } \\
\text { nasilneži }\end{array}$ & $\begin{array}{c}\text { Kronične } \\
\text { žrtve/ } \\
\text { Kronični } \\
\text { nasilneži }\end{array}$ & $\chi^{2}(\mathrm{df}) \mathrm{p}$ \\
\hline \multirow{2}{*}{ Šola } & osnovna & $34.8 / 42.9$ & $50.0 / 49.1$ & $15.2 / 8.0$ & \multirow{2}{*}{$\begin{array}{r}26.158(2) .000^{* * *} \\
2.985(2) .225 \\
\end{array}$} \\
\hline & srednja & $53.8 / 50.5$ & $43.2 / 44.9$ & $3.0 / 4.7$ & \\
\hline \multirow{2}{*}{ Spol } & fantje & $50.6 / 36.1$ & $43.8 / 54.5$ & $5.6 / 9.6$ & \multirow{2}{*}{$\begin{array}{c}.561(2) .755 \\
23.853(2) .000^{* * *}\end{array}$} \\
\hline & dekleta & $47.2 / 57.8$ & $46.0 / 39.6$ & $6.8 / 2.6$ & \\
\hline \multirow{3}{*}{$\begin{array}{l}\text { Obdobje } \\
\text { mladostni- } \\
\text { štva }\end{array}$} & zgodnje & $37.2 / 46.5$ & $51.2 / 46.5$ & II. $6 / 7.0$ & \multirow{3}{*}{$\begin{array}{l}11.318(4) .023^{*} \\
2.225(4) .694\end{array}$} \\
\hline & srednje & $46.8 / 45 \cdot 9$ & $45.9 / 50.5$ & $7.3 / 6.7$ & \\
\hline & pozno & $54.1 / 50.5$ & $42.2 / 43.6$ & $3.7 / 6.0$ & \\
\hline \multirow{5}{*}{ Učni uspeh } & $\mathrm{I}$ & $37.5 / 25.0$ & $37.5 / 37.5$ & $25.0 / 37.5$ & \multirow{5}{*}{$\begin{array}{c}\text { I2.95I (8).II } 4 \\
34.802(8) .000^{* * *}\end{array}$} \\
\hline & 2 & $43.8 / 31.2$ & $43.8 / 43.8$ & $\mathrm{I} 2.5 / 25.0$ & \\
\hline & 3 & $52.7 / 43.3$ & $41.9 / 53.3$ & $5.4 / 3.1$ & \\
\hline & 4 & $53.0 / 53.6$ & $43.0 / 40.6$ & $4.0 / 6.0$ & \\
\hline & 5 & $38.9 / 51.9$ & $52.8 / 45 \cdot 4$ & $8.3 / 2.8$ & \\
\hline
\end{tabular}

Opombe. $p<.05^{*} ; p<.001^{* * *}$.

učencev, ki niso aktivno udeleženi v MVN, s starostjo povečuje, število kroničnih žrtev pa zmanjšuje. Med učenci, ki ne sodelujejo v MVN, je pomembno več učno uspešnih učencev.

V Sloveniji smo v zadnjih dvajsetih letih priča tudi iniciacijskemu obredu ob sprejemu novincev v srednjo šolo, imenovanem $\gg$ fazaniranje $\ll$. Ta pojav v slovenskem prostoru s psihološkega vidika še ni bil - razen enega diplomskega dela (Kebler, 20ı6) - ustrezno raziskan. Zato smo s prvo večjo psihološko študijo na to temo v Sloveniji želeli raziskati ta obred (Pečjak in Pirc, 2019). Obred »fazaniranja «, ki je prisoten praktično na vseh šolah, poteka kot »uradno fazaniranje «, ki ga organizirajo šole, in kot »neuradno fazaniranje «, ko starejši dijaki izvajajo določene dejavnosti z novinci v šoli in izven nje. Tovrstni obred lahko ob zmanjšani kontroli avtoritet vodi $v$ nasilje in izživljanje nad dijaki-novinci, kar ima lahko zanje hude posledice.

Z eksploratorno študijo (Pečjak in Pirc, 2019), v kateri so sodelovali dijaki prvih letnikov ( $\mathrm{N}=404)$, smo tako želeli: I) ugotoviti razširjenost neuradnega »fazaniranja «, kraje, kjer se to dogaja, ter (ne)prostovoljno vključenost novincev vanj; 2) določiti vrsto in pogostost posameznih dejavnosti »fazaniranja $\operatorname{ter} 3$ ) raziskati, kako novinci (tarče, opazovalci ter tisti v dvojni vlogi tarče-opazovalci) doživljajo »fazaniranje« in kakšna stališča ter občutja imajo 
Tabela 2: Vrste in pogostost izvajanja posameznih aktivnosti fazaniranja.

\section{Vrste fazaniranja $\mathrm{z}$ aktivnostmi}

\section{Nedolžno fazaniranje}

Pisanje s flomastri po koži/oblačilih novincev, klicanje novincev s $\gg$ frrrr«, javno nastopanje pred publiko (petje, plesanje ...); barvanje las, obleke, kože s pršilom; izvajanje nenavadnih aktivnosti, kot so merjenje hodnika s kovancem, tuljenje v luno; vzpostavitev stika z določeno (neznano) osebo; izvajanje določene aktivnosti z zavezanimi očmi itd.

\begin{tabular}{|c|c|c|}
\hline Skupno število aktivnosti/povprečje aktivnosti na novinca & $734 / 1.8$ & 72 \\
\hline \multicolumn{3}{|l|}{ Fazaniranje z elementi MVN } \\
\hline \multicolumn{3}{|l|}{$\begin{array}{l}\text { Polivanje novincev z vodo; uživanje ekstremno pekoče hrane (feferonov, } \\
\text { čilija), obmetavanje novincev s hrano (jajci, paradižnikom), simuliranje } \\
\text { spolnega odnosa z drugo osebo (istega ali nasprotnega spola) itd. }\end{array}$} \\
\hline Skupno število aktivnosti/ povprečje aktivnosti na novinca & $230 / 0.6$ & 22.5 \\
\hline \multicolumn{3}{|l|}{ Nasilno/nevarno fazaniranje } \\
\hline \multicolumn{3}{|l|}{$\begin{array}{l}\text { Spodbujanje novinca k uživanju pretiranih količin alkohola, k uživanju } \\
\text { snovi, ki se normalno ne uživajo, fizično nasilje nad novinci (brce, udarci, } \\
\text { pranje glave v WC, spodbujanje h kraji tuje lastnine). }\end{array}$} \\
\hline Skupno število aktivnosti/ povprečje aktivnosti na novinca & $56 / 0.14$ & 5.5 \\
\hline Skupno število vseh poročanih aktivnosti & $1020 / 2.5$ & 100.0 \\
\hline
\end{tabular}

Ugotovili smo, da je to široko razširjen pojav, saj kar 79 \% novincev poroča, da so bili v neuradno »fazaniranje « vključeni kot tarče oz. tarče-opazovalci, od tega kar 43 \% med njimi neprostovoljno. Nadalje smo ugotovili, da neuradno »fazaniranje « najpogosteje poteka kar na šoli oz. v njeni okolici. To je že prvi pomemben signal šolam, da so (so)odgovorne tudi za to, kar počnejo starejši dijaki mlajšim pri neuradnem »fazaniranju «. Na šolah bi bilo treba vpeljati t. i. avtoritativno disciplino (Gregory et al., 20Io), ki temelji na jasnih pravilih glede tega, pod kakšnimi pogoji lahko starejši dijaki iniciirajo novince (ne brez njihovega dovoljenja oz. soglasja), ter na razpoložljivosti odraslih (učiteljev), ki lahko podprejo novince pri njihovi odločitvi, da ne sodelujejo pri »fazaniranju«.

Glede na vrsto aktivnosti pri »fazaniranju « smo uporabili klasifikacijo Lundeena (2013), ki deli iniciacijske obrede v tri kategorije: nedolžno/ neškodljivo »fazaniranje «, »fazaniranje « kot MVN in nasilno/kriminalno $\gg$ fazaniranje $\ll$ (Tabela 2$)$.

Kot je razvidno iz poročanja tistih novincev, ki so bili aktivno udeleženi v nasilju, je bil vsak od njih v povprečju udeležen 2.5-krat. Večina novincev je bila deležna nedolžnega oz. neškodljivega »fazaniranja $\ll$ (v $72 \%$ primerov). Pri tem je bila daleč najbolj pogosta aktivnost popisovanje 
novincev s flomastri po koži in oblačilih, saj kar $85 \%$ tarč poroča o tem. Druge aktivnosti so bile prisotne $v$ manjši meri. $O \gg$ fazaniranju $\ll z$ elementi nasilja poroča $22.5 \%$ novincev, kar pomeni, da je bil vsak drugi novinec udeležen pri aktivnosti, ki bi jo lahko označili kot MVN. Pri tem so jih najpogosteje polivali z vodo (v $25 \%$ ), silili k uživanju ekstremno pekoče hrane (v $16 \%$ ) ali obmetavali s hrano (v $14 \%$ ). Vsak sedmi novinec pa je bil izpostavljen aktivnostim nasilnega $\gg$ fazaniranja $\ll$ - najpogosteje je moral zaužiti pretirano količino alkohola ( $5.7 \%)$, uživati snovi, ki se sicer normalno ne uživajo ( $5.4 \%$ ), ali pa je bil žrtev fizičnega nasilja.

Tretji cilj je bil ugotoviti, kakšna stališča in občutja v zvezi $s \gg$ fazaniranjem « imajo dijaki, ki so bili tarče, tisti v dvojni vlogi tarče-opazovalca in opazovalci. Rezultati so zanimivi zlasti v tistem delu, ki kaže, da so najbolj kritični do tega pojava opazovalci. Ti imajo namreč pomembno bolj negativna stališča do $\gg$ fazaniranja $\ll$ v primerjavi s tarčami in tarčami-opazovalci $\left(F(2)=2.49, p<.05, \eta^{2}=.190\right)$ ter tudi pomembno bolj negativna občutja kot ostali dve skupini ob opazovanju »fazaniranja « $\left(F(2)=11.92, p<.001, \eta_{2}=.278\right)$. Velikost učinka teh razlik pri opazovalcih je tako pri stališčih kot občutjih do »fazaniranja« velika. Poročajo, da predstavlja »fazaniranje « poniževanje novincev, da jim je ob tem neprijetno in da so prizadeti. Zato se postavlja vprašanje, zakaj opazovalci ne naredijo česa, da bi zaustavili »fazaniranje«, še zlasti, kadar preraste iz blažjih oblik v nasilje. Razloge za to verjetno lahko iščemo v različnih mehanizmih moralnega opravičevanja, kot npr., da gre za tradicijo (Bandura, 1999), in/ali v njihovi potrebi po konformiranju. Poleg tega imajo opazovalci dijaki-novinci malo socialne moči in veliko potrebo po pripadnosti šoli. Zato dijaki prvih letnikov praviloma težje zaustavijo nasilje pri »fazaniranju «. To lažje naredijo dijaki višjih letnikov, ki imajo več socialne moči in višjo socialno pozicijo.

Zaradi moči, ki jo imajo pri MVN v šolah opazovalci, to vlogo v nadaljevanju podrobneje predstavljamo.

\section{Vloge opazovalcev pri medvrstniškem nasilju}

V skoraj petdesetletnem raziskovanju $M V N$ v šoli so raziskovalci večji del pozornosti namenjali dvema vlogama učencev, ki sta bili aktivno udeleženi v MVN - nasilnežu in žrtvi. Ugotavljali so njune značilnosti, ogrožajoče in varovalne dejavnike pri enem in drugem ipd. Bistveno manjša pozornost pa je bila namenjena množici tistih, ki so pri tem nasilju prisotni kot opazovalci. Zavedati se je treba, da pri MVN ne gre le za diadni odnos med nasilnežem in žrtvijo, pač pa so vanj hote ali nehote vključeni tudi tisti, ki so prisotni ob teh dejanjih - učenci opazovalci. MVN naj bi se namreč kar v 85-ih odstotkih odvijalo ob prisotnosti vrstnikov (Pepler in 
Craig, 1995). Učenci-opazovalci predstavljajo prevladujočo skupino učencev $\mathrm{v}$ razredih in imajo veliko socialno moč, ki pa jo šole pogosto - iz različnih razlogov - ne izkoristijo (ali ne znajo izkoristiti) za zaustavitev MVN. Kar 90 odstotkov starejših osnovnošolcev namreč poroča, da ne naredijo nič, če so priče MVN (Pergolizzi et al., 2009).

Opazovalci niso homogena skupina, ampak se ločijo glede na svojo »držo« pri MVN. Pri tem najpogosteje govorimo o naslednjih skupinah opazovalcev: ignoranti (učenci, ki opazujejo, vendar ne posegajo v situacijo nasilja); pasivni spodbujevalci (s pozornostjo opazujejo nasilje in/ali se smejijo žrtvam); aktivni spodbujevalci (nasilnež jim predstavlja model, zato ga z različnimi pripombami in predlogi spodbujajo ali se mu celo pridružijo) in zagovorniki žrtve (žrtev skušajo braniti pred nasilnežem ali jo potolažiti) (Rigby in Johnson, 2006; Whitney in Smith, 1993).

Zato je zanimivo raziskovalno vprašanje, kaj je tisto, kar odloči, ali se bo nekdo kot opazovalec postavil žrtvi v bran ali bo ostal nevtralen ali bo celo stopil na stran nasilneža. To smo ugotavljali v raziskavi, v katero je bilo vključenih 590 učencev osnovne in srednje šole, ki so bili enakomerno zastopani glede na spol in stopnjo šolanja (Pečjak in Pirc, 2014). Najprej smo jih glede na njihove odgovore na Vprašalniku nasilja v šoli (Cheng et al., 20II)I razvrstili v običajne vloge pri MVN - v nasilneže, žrtve, žrtve-nasilneže in neudeležene. Nato pa smo pri istih učencih z Vprašalnikom vloge opazovalcev (Parada, 2000)2 ugotavljali, v kakšni vlogi bi se posamezne skupine učencev znašle, če bi prisostvovali MVN kot opazovalci (Tabela 3).

Rezultati kažejo, da učenci, ki so pri MVN v vlogi nasilnežev ali nasilnežev in žrtev hkrati, pri opazovanju MVN pomembno pogosteje kot ostali učenci zavzamejo vlogo aktivnih spodbujevalcev nasilneža $(d f=\mathbf{I}$, $F=30.78, p<.000)$. Vlogo pasivnih spodbujevalcev pa pogosteje kot ostali učenci zavzamejo nasilneži-žrtve $(d f=\mathrm{I}, F=5 \mathrm{r} .02, p<.000)$. Med ignoranti so vloge dokaj enakomerno razporejene, pri čemer je opazno višje povprečje pri žrtvah in nasilnežih-žrtvah. Med zagovorniki žrtve pa je pomembno manj nasilnežev in nasilnežev-žrtev $(d f=\mathrm{I}, F=4.20, p<.05)$. Opozoriti velja še na precejšnjo variabilnost rezultatov pri učencih, ki so hkrati nasilneži in žrtve - pri njih je najteže napovedati, katero vlogo bodo zavzeli kot opazovalci MVN. Zato bi bilo smiselno to dvojno vlogo učencev v nadaljnjih raziskavah podrobneje raziskati/osvetliti.

I Prevod in priredba v slovenščino S. Jakin in S. Pečjak (20I3). Opis in vprašalnik sta v knjigi Pečjak, S. (2015). Medvrstniško nasilje v šoli. Ljubljana: Filozofska fakulteta.

2 Prevod v slovenščino S. Pečjak (20I4). Opis in vprašalnik je v knjigi Pečjak, S. (2OI5). Medvrstniško nasilje v šoli. Ljubljana: Filozofska fakulteta. 
Tabela 3: Pogostost pojavljanja učencev z določeno vlogo v MVN, kadar so opazovalci takšnega nasilja.

\begin{tabular}{|c|c|c|c|c|}
\hline & $\begin{array}{c}\text { Aktivni } \\
\text { spodbujevalec }\end{array}$ & $\begin{array}{c}\text { Pasivni } \\
\text { spodbujevalec }\end{array}$ & Ignorant & $\begin{array}{l}\text { Zagovornik } \\
\text { žrtve }\end{array}$ \\
\hline $\begin{array}{l}\text { Vloga učenca } \\
\text { vMVN }\end{array}$ & $\mathrm{M}(\mathrm{SD})$ & $\mathrm{M}(\mathrm{SD})$ & $\mathrm{M}(\mathrm{SD})$ & $\mathrm{M}(\mathrm{SD})$ \\
\hline Neudeleženi & $8.24(4.6 \mathrm{I})$ & $11.74(6.38)$ & $14.39(7.45)$ & $22.94(9.56)$ \\
\hline Nasilneži & $13.93(9.29)$ & $15.72(7.60)$ & $13.52(6.50)$ & $18.52(11.26)$ \\
\hline Žrtve & $9.53(6.27)$ & $15.61(12.13)$ & $15.25(10.09)$ & $20.39(10.37)$ \\
\hline Nasilneži-žrtve & $15.00(9.25)$ & $32.64(22.7 \mathrm{I})$ & $16.18(7.65)$ & $17.09(10.20)$ \\
\hline
\end{tabular}

Ugotovili smo še, da je med aktivnimi spodbujevalci pomembno več osnovnošolcev, fantov in učno manj uspešnih učencev. Velikosti učinkov teh razlik so pri osnovnošolcih in fantih velike $\left(d^{\beta}=.70, .27\right)$, pri učno manj uspešnih pa srednje $(d=.20)$. Med pasivnimi spodbujevalci je prav tako pomembno več osnovnošolcev in fantov $(d=.65$ in .2I). Med ignoranti pa je več dijakov kot osnovnošolcev in več učno uspešnejših učencev $(d=.16$ in .r9). Pokazalo se je še, da so dekleta in srednješolci večkrat v vlogi zagovornikov žrtve $(d=.20$ in .40).

Skladno z ugotovitvami že navedenih študij tudi naši rezultati potrjujejo splošno dejstvo, da je manj MVN pri dekletih (Crapanzano et al., 20II; Demaray in Kerres Malecki, 2003; Pozzoli, Ang in Gini, 2012). To bi lahko razložili s podobnimi socializacijskimi procesi pri dekletih, ki so neodvisni od kulture, kot so npr. spodbujanje razvoja empatije ter pomoči šibkejšim in tistim, ki jo potrebujejo (Ang in Goh, 20IO; Espelage, Mebane in Adams, 2004; Pellegrini, 2002). Za fante pa je, ne glede na kulturo, bolj značilno izkazovanje moči in dominantnosti, kar se lahko pokaže tudi pri MVN (pogosteje so aktivni in pasivni spodbujevalci nasilja).

Različne vloge zavzemajo učenci tudi glede na stopnjo šolanja, pri čemer so dijaki kot opazovalci manj pogosto spodbujevalci nasilneža. To kaže - kot je bilo tudi že omenjeno - na dozorevanje in večjo socialno kompetentnost pri dijakih. Obenem pa je treba izpostaviti, da prav dijaki pomembno pogosteje kot učenci osnovne šole ignorirajo MVN. Verjetno lahko vzroke iščemo $\mathrm{v}$ šolski kulturi, ki več pozornosti kot socialnim posveča učnim ciljem. MVN pogosteje ignorirajo tudi učno uspešnejši učenci, ki so po navadi bolj socialno kompetentni, kar bi lahko prav tako nakazovalo na razvoj individualistične šolske kulture, ki daje prednost skrbi zase pred skrbjo za druge. Še en možen razlog pa bi lahko bil v razpršeni odgovornosti med opazovalci (»učinek opazovalcev«, Darley in Latané, 1968). To pomeni, da zaradi večjega števila opazovalcev vsak pričakuje, da $3 d=0.20-$ majhen učinek; $d=0.50-$ srednji učinek; $d=0.80-$ velik učinek (Cohen, 1988). 
bo nekdo drug pomagal žrtvi, ali pa se jim situacija ne zdi dovolj resna, če ne vidijo, da bi kdo ukrepal. Ti rezultati nakazujejo na velik pomen šolske kulture na področju MVN.

\section{Šolska kultura in MVN}

Kot smo že izpostavili, MVN ne vpliva le na žrtve, pač pa tudi na vse ostale, ki so v šolskem prostoru priča temu nasilju (opazovalce), in na tiste, ki o njem samo slišijo (Bronfenbrenner, 1979). To nazorno razlaga model valujočega učinka (Sullivan, 20II), v katerem avtor primerja MVN s kamnom, ki ga vržemo v vodo, potem pa se okrog njega $v$ koncentričnih krogih širijo valovi - najprej manjši, potem vedno večji. Omenjeni model govori o petih stopnjah tega »valovanja《 oz. učinkovanja. Na prvi stopnji je MVN povezano z žrtvijo, ki čuti breme nasilja, na drugi stopnji so posredne žrtve nasilja starši in družine otrok - žrtev in nasilnežev -, na tretji stopnji vpliva tudi na tiste, ki so mu priča - torej na opazovalce/vrstnike. Poudarja, da je zelo pomembno, kako se na tej stopnji na nasilje odzove šola, saj je to simbolna informacija za vse opazovalce. Če vidijo, da poskuša šola vedno znova zaustavljati nasilje, potem je večja verjetnost, da ga tudi opazovalci ne bodo odobravali, da ga bodo poskušali zaustaviti sami ali pa bodo o njem vsaj poročali odraslim - učiteljem ali staršem. Reakcija šole na MVN je jasno sporočilo tudi drugim učencem in učiteljem na šoli - da se nasilje ne bo toleriralo. Če je odziv na MVN slab in neučinkovit, potem je to sporočilo nasilnežem, da lahko nadaljujejo z njim, ne da bi bili kaznovani. Če šola sploh ne reagira na MVN, pa je to neposreden prispevek k oblikovanju kulture nasilja na šoli.

V domači študiji (Pečjak in Pirc, 2017) smo raziskovali, kako šolsko klimo dojemajo različne skupine nasilnežev (občasni in kronični), žrtev (občasne in kronične) in nevključeni učenci. Tovrstni podatki so pomembno izhodišče za načrtovanje različnih preventivnih in intervencijskih aktivnosti na šolah v zvezi z MVN.

Rezultate smo zbrali $\mathrm{z}$ Vprašalnikom šolske klime pri MVN (Cornell, 20I2), ki meri tri dimenzije šolske klime na področju MVN: razširjenost MVN (s postavk), agresivna stališča (7 postavk) in pripravljenost za iskanje pomoči ( 9 postavk). Učenci so odgovarjali na 4-stopenjski lestvici ( $\mathrm{I}$ - sploh se ne strinjam, 4 - popolnoma se strinjam), pri čemer višji rezultat kaže na bolj izraženo dimenzijo šolske klime pri MVN (Tabela 4).

Rezultati kažejo na obstoj pomembnih razlik med posameznimi skupinami žrtev v zaznani razširjenosti MVN (s to dimenzijo lahko pojasnimo kar $51 \%$ variabilnosti v zaznavah šolske klime) in v agresivnih stališčih (z njimi lahko pojasnimo 26 \% razlik v zaznani šolski klimi). S post 
Tabela 4: Razlike v zaznani šolski klimi med učenci, ki niso žrtve, občasnimi žrtvami in kroničnimi žrtvami.

\begin{tabular}{|c|c|c|c|c|c|c|}
\hline \multirow[t]{2}{*}{ Šolska klima } & $\begin{array}{l}\text { Učenci } \\
\text { ne-žrtve }\end{array}$ & $\begin{array}{c}\text { Občasne } \\
\text { žrtve }\end{array}$ & $\begin{array}{c}\text { Kronične } \\
\text { žrtve }\end{array}$ & \multirow{2}{*}{$\begin{array}{c}F \\
(\mathrm{df}=2)\end{array}$} & \multirow[t]{2}{*}{$\mathrm{p}$} & \multirow[t]{2}{*}{$\eta^{2}$} \\
\hline & $\mathrm{M}(\mathrm{SD})$ & $\mathrm{M}(\mathrm{SD})$ & $\mathrm{M}(\mathrm{SD})$ & & & \\
\hline $\begin{array}{l}\text { Razširjenost } \\
\text { MVN }\end{array}$ & $10.49(2.7 \mathrm{I})$ & II.I2 (2.64) & $13.54(2.39)$ & 16.140 & $.000^{* * *}$ & $.5 \mathrm{I}$ \\
\hline Agresivna stališča & $\mathrm{I} 2.2 \mathrm{I}(4.10)$ & $\mathrm{I} 2.12(3.68)$ & $14.40(4.56)$ & 3.783 & $.024^{*}$ & .26 \\
\hline $\begin{array}{l}\text { Pripravljenost } \\
\text { za iskanje pomoči }\end{array}$ & $24.74(4.75)$ & $24.59(5.06)$ & $23.56(4.89)$ & .650 & .523 & .07 \\
\hline
\end{tabular}

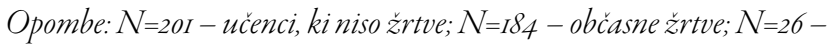
kronične źrtve; $p<.05^{*} ; p<.00 I^{* * *} ; \eta 2$ - velikost ućinka; Razsirjenost $M V N$ : min=5, max $=20 ;$ Agresivna stališca: $\min =7, \max =28 ;$ Pripravljenost $z$ a iskanje pomoci: min= $=9$, max $=36$.

hoc testi smo ugotovili, da kronične žrtve v pomembno večji meri zaznavajo, da šola dopušča MVN glede oblačil, narodnosti in spolne usmerjenosti, kot to zaznava skupina občasnih žrtev ( $\mathrm{I}-\mathrm{J}=2.3156, p<.000)$; najmanj pa to zaznavajo učenci, ki niso žrtve MVN $(\mathrm{I}-\mathrm{J}=.7303, p<.05)$. Tako občasne kot kronične žrtve torej zaznavajo več MVN v primerjavi z učenci, ki niso žrtve. Učenci žrtve imajo občutek, da šola dopušča različne oblike nasilja. Hkrati pa se zdi, da učenci, ki niso žrtve, morda niso dovolj občutljivi na ta pojav - kot da MVN ne obstaja, če se to ne dogaja njim. Do takšne naravnanosti pride $\mathrm{v}$ individualistično orientirani šolski klimi, kjer je prisotna filozofija, da zadošča, če vsak poskrbi le zase - tako na učnem kot na socialnem področju.

Ugotovili smo tudi, da imajo kronične žrtve bolj agresivna stališča kot občasne žrtve $(\mathrm{I}-\mathrm{J}=-2.2798, p<.05)$ in kot učenci, ki niso žrtve MVN $(\mathrm{I}-\mathrm{J}=-2.1889, p<.05)$. Kronične žrtve zaznavajo, da šola dopušča MVN za socialno afirmacijo učencev - da je torej agresivnost sprejemljiv način dokazovanja učencev in način zabavanja $\mathrm{z}$ vrstniki ter da agresivne reakcije predstavljajo enega sprejemljivih načinov razreševanja konfliktov.

Razlike v zaznavah šolske klime na področju MVN pri nasilnežih so prikazane v Tabeli 5 .

Največje razlike med posameznimi skupinami so se pokazale pri agresivnih stališčih, pri čemer rezultati kažejo, da so kronični nasilneži pomembno bolj prepričani, da šola v socialnih situacijah dopušča dokazovanje $s$ pomočjo nasilja, kot so $\mathrm{v}$ to prepričani občasni nasilneži (post-hoc test $\mathrm{I}-\mathrm{J}=4.2273, p<.000$ ), ti pa $\mathrm{v}$ to verjamejo pomembno bolj kot učenci, ki niso nasilni (I-J=-I.3795, $p<.000)$. Rezultati kažejo nekoliko manjše, vendar pomembne razlike tudi v pripravljenosti učencev za iskanje 
Tabela s: Razlike v zaznavah šolske klime med učenci, ki niso nasilni, občasnimi nasilneži in kroničnimi nasilneži.

\begin{tabular}{|c|c|c|c|c|c|c|}
\hline \multirow[t]{2}{*}{ Šolska klima } & $\begin{array}{c}\text { Učenci } \\
\text { ne-nasilneži }\end{array}$ & $\begin{array}{l}\text { Občasni } \\
\text { nasilneži }\end{array}$ & $\begin{array}{l}\text { Kronični } \\
\text { nasilneži }\end{array}$ & \multirow{2}{*}{$\begin{array}{c}F \\
(\mathrm{~d} f=2)\end{array}$} & \multirow[t]{2}{*}{$\mathrm{p}$} & \multirow[t]{2}{*}{$\eta^{2}$} \\
\hline & $\mathrm{M}(\mathrm{SD})$ & $\mathrm{M}(\mathrm{SD})$ & $\mathrm{M}(\mathrm{SD})$ & & & \\
\hline $\begin{array}{l}\text { Razširjenost } \\
\text { MVN }\end{array}$ & $10.7 \mathrm{I}(2.80)$ & II.2I $(2.73)$ & $12.04(2.27)$ & 3.389 & $.035^{*}$ & .03 \\
\hline Agresivna stališča & $11.29(3.84)$ & $12.82(3.64)$ & $17.05(3.7 \mathrm{I})$ & 26.650 & $.000^{* * *}$ & .42 \\
\hline $\begin{array}{l}\text { Pripravljenost } \\
\text { za iskanje pomoči }\end{array}$ & $25.15(4.86)$ & $24.33(4.89)$ & 21.9I (4.10) & 5.142 & $.006^{* *}$ & .14 \\
\hline
\end{tabular}

Opombe: $N=200$ - učenci, ki niso nasilni; $N=185$-obćasni nasilnež $i ; N=23$ - kronični nasilneži; $p<05^{*} ; p<.0 I^{* *} ; p<.00 I^{* * *} ; \eta 2$ - velikost ucinka; Razšrirjenost $M V N$ : min=5, max=20; Agresivna stališca: $\min =7, \max =28 ;$ Pripravljenost za iskanje pomoci $:$ min $=9, \max =36$.

pomoči - kronični nasilneži so najmanj pripravljeni iskati pomoč pri učiteljih, občasni bolj in nenasilneži najbolj. Hkrati kronični nasilneži najbolj zaznavajo učitelje, kot da jim ni mar, kako se učenci počutijo, da učencem ne povedo jasno, da nasilja ne bodo dopuščali ter da je pravila treba upoštevati. Dobljeni rezultati so skladni s teorijo avtoritativne discipline (Gregory in Cornell, 2009), ki poudarja potrebo po jasnih šolskih pravilih in učiteljevi podpori pri uveljavljanju teh pravil v razredu $\mathrm{z}$ namenom zmanjševanja MVN. Primerjava med kroničnimi in občasnimi žrtvami pokaže, da imajo slednje manj izražena agresivna stališča do vrstnikov, da so hitreje pripravljene poiskati pomoč učitelja v povezavi z MVN in da v splošnem zaznavajo šolsko klimo kot bolj podporno. Dobljeni rezultati nakazujejo, da je na šolah - poleg krizno-kurativnega dela s kroničnimi nasilneži - smiselno oz. pomembno tudi preventivno delo z občasnimi nasilneži. Glede na to, da imajo ti ugodnejša prepričanja, lahko sklepamo, da bi s takšnim pristopom hitreje in bolj učinkovito delovali na zmanjšanje nasilja z njihove strani kot $\mathrm{v}$ primeru kroničnih nasilnežev.

\section{Vloga učiteljev pri oblikovanju šolske kulture na področju medvrstniškega nasilja}

Izpostavili smo že, da imajo pri ustvarjanju šolske kulture, ki ne dopušča MVN, zelo pomembno vlogo učitelji. Zaradi svojega položaja so verjetno učitelji tisti, ki imajo največjo moč za zaustavitev tega nasilja na šoli. Pri tem pa je od njihove senzibilnosti odvisno, ali oz. v kolikšni meri bodo zaznali to nasilje. Zato je seveda pomembno vprašanje, kateri dejavniki so tisti, ki napovedujejo večjo občutljivost učiteljev za zaznavanje in posledično za obravnavo oz. zaustavitev MVN. Študije kažejo, da je stopnja 
senzibilnosti učiteljev odvisna od njihovih lastnih izkušenj z MVN, ki vplivajo na njihova prepričanja o tem pojavu, od zaznane kompetentnosti za spoprijemanje s takimi situacijami in od tega, v kolikšni meri se učitelji zavedajo negativnih posledic MVN (Bradshaw, Sawyer in O'Brennan, 2007; Sullivan, 201 ). Zato avtorji teh študij poudarjajo, da sta senzibilizacija učiteljev v zvezi z MVN in spodbujanje, da se nanj takoj odzovejo, pomembna tako $\mathrm{v}$ procesu izobraževanja prihodnjih učiteljev kot tudi v njihovem nadaljnjem profesionalnem razvoju.

Številne empirične študije kažejo, da so učiteljeva prepričanja o resnosti MVN eden od pomembnih napovednikov njihovih intervencij, pri čemer pa učitelji različne vrste MVN zaznavajo kot različno resne oz. ogrožajoče za psihično blagostanje učencev (Bauman in Del Rio, 2006; Craig, Bell in Leschied, 201; Ellis in Schutte, 2007; Holt in Keyes, 2004). Yoon in Kerber (2003) navajata rezultate študije, v kateri sta ugotovila, da učitelji kažejo pomembno nižjo stopnjo empatije do žrtev odnosnega kot do žrtev fizičnega in verbalnega nasilja ter da so pripravljeni posledično kar petkrat redkeje zaustaviti odnosno nasilje v primerjavi s fizičnim in verbalnim.

Zato smo v študiji (Pečjak in Pirc, 2015) želeli ugotoviti, kako slovenski učitelji zaznavajo resnost fizičnega, verbalnega in odnosnega nasilja, kakšna je njihova empatija do žrtev posameznih vrst nasilja in kako pripravljeni so posredovati pri različnih vrstah nasilja (Tabela 6). V študiji je sodelovalo 70 učiteljev iz šestih slovenskih šol, pri čemer je bilo $32 \%$ učiteljev z razredne in $68 \%$ učiteljev s predmetne stopnje (od tega $34 \%$ učiteljev naravoslovnih in $34 \%$ učiteljev družboslovnih predmetov.

Tabela 6: Zaznave posameznih vrst MVN pri učiteljih ( $\mathrm{N}=70$ učiteljev).

\begin{tabular}{lccc} 
Vrste MVN & $\begin{array}{c}\text { Resnost MVN } \\
\text { M (SD) }\end{array}$ & $\begin{array}{c}\text { Empatija do žrtev } \\
\text { M (SD) }\end{array}$ & $\begin{array}{c}\text { Potreba } \\
\text { po intervenciji } \\
\text { M (SD) }\end{array}$ \\
Verbalno & $4.60(0.86)$ & $3.90(\mathrm{I} .97)$ & $4.86(0.54)$ \\
\hline Fizično & $4.6 \mathrm{I}(0.91)$ & $3.96(\mathrm{I} .54)$ & $4.79(0.69)$ \\
\hline Odnosno & $3.69(\mathrm{I} .56)$ & $3.64(\mathrm{I} .64)$ & $4.18(\mathrm{I} .28)$ \\
\hline
\end{tabular}

Rezultati, dobljeni na slovenskem vzorcu učiteljev, so podobni tistim $\mathrm{v}$ tujih študijah - učitelji dejansko zaznavajo fizično in verbalno nasilje kot bolj resni obliki nasilja, so tudi bolj empatični do žrtev obeh omenjenih vrst nasilja in poročajo o večji potrebi po intervenciji v primeru fizičnega in verbalnega nasilja (Bauman in Del Rio, 2006; Kochenderdfer-Ladd in Pelletier, 2008; Nishina in Juvonen, 2005). Razlogi za takšne podatke so različni. Najprej: odnosno nasilje je težje zaznati kot fizično oz. verbalno, 
saj je zelo subtilno (Bauman in Del Rio, 2006). Hkrati pa je tudi težje predvideti, kako bo to nasilje delovalo na žrtev, če jo npr. izključijo iz skupine učencev, ki se igra skupaj. Nekateri raziskovalci tudi opozarjajo na napačna prepričanja učiteljev, da je odnosno nasilje nekaj normativnega, še zlasti v obdobju zgodnjega in srednjega mladostništva (Vernberg in Gamm, 2003; Yoon in Kerber, 2003). Dobljeni podatki navajajo na to, da je treba pri učiteljih ozavestiti dejstvo, da ima to nasilje enako škodljive posledice za žrtve in nasilneže kot ostali dve obliki nasilja in da ga je zato treba tudi enako obravnavati.

Drugo raziskovalno vprašanje je bilo, kaj napoveduje intervencije učiteljev pri posameznih vrstah nasilja ter kakšne so te intervencije do žrtev in nasilnežev. Rezultati hierarhične regresijske analize za posamezne vrste nasilja so prikazani v Tabeli 6 .

Tabela 7: Napovedniki intervencij pri učiteljih.

\begin{tabular}{llccc} 
& \multirow{2}{*}{$\begin{array}{c}\text { Učitelji } \\
\text { verbalno }\end{array}$} & \multicolumn{3}{c}{ Vrsta nasilja } \\
\cline { 3 - 5 } & & fizično & odnosno & $\beta$ \\
\hline \multirow{3}{*}{ I. korak } & spol & .16 & $\beta$ & .07 \\
\cline { 2 - 5 } & smer poučevanja & .32 & .23 & .24 \\
\cline { 2 - 5 } & leta poučevanja & .14 & $.21^{*}$ & $.20^{*}$ \\
\hline \multirow{3}{*}{2. korak } & $\mathrm{R} / \mathrm{R}^{2}$ & $.26 / .07$ & $.38 / .14$ & $.40 / .16$ \\
\hline & $\Delta \mathrm{R}$ & .07 & $.14^{*}$ & $.16^{*}$ \\
\hline & resnost & $.25^{*}$ & $.57^{* * *}$ & $.46^{* * *}$ \\
\cline { 2 - 5 } & $\mathrm{empatija} \mathrm{do} \mathrm{žrtve}$ & .18 & .04 & $.23^{*}$ \\
\hline & $\mathrm{R} / \mathrm{R}^{2}$ & $.40 / .16$ & $.67 / .45$ & $.70 / .49$ \\
& $\Delta \mathrm{R}$ & $.09^{*}$ & $.31^{* * *}$ & $.33^{* * *}$ \\
\hline
\end{tabular}

Opombe: $N=$ 7o uciteljev; $p<.05^{*} ; p ; p<.0 I^{* *} ; p<.00 I^{* * *} ; \beta$ - standardizirani $\beta$ koeficient; $R$ - koeficient multiple korelacije, $R^{2}$ - koeficient determinacije; $\Delta R$-sprememba koeficienta multiple korelacije.

S postavljenim modelom smo lahko pojasnili le I6 \% variabilnosti v intervencijah učiteljev pri verbalnem nasilju, pomembno večji delež razlik med učitelji pa pri fizičnem (45\%) in še večji delež pri odnosnem nasilju (kar 49 \% vseh razlik med učitelji). Pri tem se je kot najpomembnejši napovednik učiteljevih intervencij pri vseh treh vrstah nasilja pokazala zaznana resnost nasilja pri učitelju. Bolj resno, kot ga zaznavajo, prej oz. pogosteje so pripravljeni posredovati. Drug pomemben napovednik pa so leta poučevanja. Učitelji z daljšim učiteljskim stažem so bolj občutljivi za fizično in odnosno nasilje kot mlajši učitelji. Možno je, da so slednji bolj 
Tabela 8: Vrste intervencij učitelja do nasilnežev oz. žrtev MVN.

\begin{tabular}{|c|c|c|c|c|c|c|}
\hline \multirow{3}{*}{ Kategorije } & \multicolumn{6}{|c|}{ \% učiteljevih odzivov v kategoriji } \\
\hline & \multicolumn{2}{|c|}{ verbalno } & \multicolumn{2}{|c|}{ fizično } & \multicolumn{2}{|c|}{ odnosno } \\
\hline & žrtve & nasilneži & žrtve & nasilneži & žrtve & nasilneži \\
\hline Brez intervencije & I.5 & 0.0 & 2.4 & 0.0 & 5.8 & 0.0 \\
\hline $\begin{array}{l}\text { Pogovor z vsemi udeležen- } \\
\text { ciMVN }\end{array}$ & 50.0 & 29.0 & 50.4 & 31.8 & 42.7 & 54.7 \\
\hline $\begin{array}{l}\text { Pogovor o pravilih vedenja } \\
\text { s celim razredom }\end{array}$ & I.5 & I.5 & 0.3 & I.5 & 2.4 & $9 \cdot 4$ \\
\hline $\begin{array}{l}\text { Izpostavitev netoleriranja } \\
\text { takega vedenja }\end{array}$ & & 11.6 & & 21.6 & & I2.5 \\
\hline Discipliniranje nasilneža & & IO.I & & 28.8 & & I4.I \\
\hline Spodbujanježrtve & 19.7 & & 22.9 & & 27.0 & \\
\hline $\begin{array}{l}\text { Neučinkovito } \\
\text { zagovornišstvo* }\end{array}$ & 1.5 & & 15.0 & & 7.8 & \\
\hline $\begin{array}{l}\text { Poročanje ravnatelju, infor- } \\
\text { miranje staršev }\end{array}$ & 22.8 & 47.8 & 9.2 & 27.3 & 3.5 & 6.2 \\
\hline Drugo & 3.0 & 0.0 & 2.5 & 0.0 & 0.9 & 3.1 \\
\hline Skupaj & 100 & 100 & 100 & 100 & 100 & 100 \\
\hline
\end{tabular}

Opombe: * Reče žrtvi, naj ignorira nasilneža.

osredotočeni na didaktične vidike kurikula (npr. na to, da bodo obravnavali vse predvidene učne vsebine) kot na vedenje učencev, zaradi česar lahko spregledajo posamezne primere MVN.

Glede na to, da se le manjše število študij ukvarja z učiteljevimi načini odzivanja na nasilje pri učencih nasilnežih in žrtvah (npr. KochenderferLadd in Pelletier, 2008; Troop in Ladd, 2002; Yoon in Kerber, 2003), smo skušali odgovoriti tudi na to vprašanje (Tabela 8 ).

V odzivanju učiteljev na nasilneže lahko odkrijemo določene trende. Prvi tak trend je, da je najpogostejši odziv pri vseh vrstah nasilja pogovor učitelja z udeleženci. Pri tem se pogosteje pogovarjajo z žrtvami kot z nasilneži - razen v primeru odnosnega nasilja, kjer se pogosteje pogovarjajo z nasilneži. V vsakem primeru se zdi, da učitelji spodbujajo medsebojno komunikacijo udeleženih v nasilju z namenom, da ti najdejo neko skupno rešitev. Ta rešitev se zdi na prvi pogled optimalna, vendar pa je pomembno, da učitelji v tej komunikaciji aktivno podpirajo žrtev, da se sooči z nasilnežem, upoštevaje dejstvo, da med njima sicer praviloma obstaja neravnovesje moči. Samo v takem primeru je ta strategija dobra in lahko vodi v zmanjšanje nasilja (Kochenderfer-Ladd in Pelletier, 2008). Sicer pa raziskava Yoona in Kerberja (2003) kaže, da učenci-žrtve največ pridobijo, če se pogovorijo z učiteljem in skupaj naredijo načrt proaktivnih dejavnosti, ki zmanjšajo tveganje za ponavljajoče se ustrahovanje. Drugi najpogostejši 
odziv učiteljev pa je, da o nasilju poročajo višji avtoriteti (ravnatelju) in z nasiljem seznanijo starše (pogosteje starše nasilnežev kot žrtev).

Zanimivo pa je, da je najredkeje uporabljena intervencija ob MVN pogovor učitelja o pravilih vedenja s celim razredom. $S$ to intervencijo bi lahko spodbudili druge učence-opazovalce, da bi se bolj aktivno vključili v zaustavljanje nasilneža oz. da bi se postavili v bran žrtvi. To kaže, da se učitelji še vedno premalo zavedajo potencialne socialne moči, ki jo imajo opazovalci pri MVN. V ta namen se nam zdi ozaveščanje in spodbujanje uporabe te strategije, še zlasti pri učiteljih-razrednikih, eden pomembnih korakov k zmanjševanju nasilja v razredih.

Poleg ozaveščanja oz. senzibiliziranja pa se nam zdi pomembno učitelje tudi usposobiti v uporabi različnih strategij za aktivno spoprijemanje z MVN in tako povečati njihov občutek kompetentnosti na tem področju. Saj, kot kažejo raziskave, se učitelji, ki se čutijo bolj kompetentni, pogosteje ustrezno odzovejo in pošljejo vsem učencem (nasilnežem, žrtvam in opazovalcem) jasno sporočilo, da nasilja ne bodo tolerirali (Doll, Song in Siemens, 2004; Yoon, 2004). Le s takimi odzivi učiteljev se lahko oblikuje varno okolje v šolah.

\section{Zaključki}

Zaključimo lahko, da bo treba v raziskovanju MVN preiti od samega opisovanja in analiziranja tega pojava v šolah $\mathrm{k}$ izdelavi in preverjanju učinkovitosti različnih preventivnih in intervencijskih programov za zmanjševanje tega nasilja. Pri tem velja, da so najbolj učinkoviti celostni programi, ki zajamejo ukrepe na ravni šole, razreda in posameznega učenca (npr. Ttoffi in Farrington, 20ı ; Vreeman in Carroll, 2007), z individualiziranimi pristopi za žrtve, nasilneže ter opazovalce. Zlasti slednji predstavljajo veliko skupino učencev, ki ima pomembno vlogo pri preprečevanju, zaustavljanju in poročanju o MVN, če se ti učenci svoje vloge zavedajo in poznajo strategije, ki jih lahko uporabijo. K učinkovitosti programov pa pomembno prispevajo tudi pripadnost učitelja programu (Smith et al., 2004b), postavljanje jasnih pravil in posledic MVN ter urjenje učiteljev in učencev v strategijah reševanja konfliktov (Vreeman in Caroll, 2007), učenje uravnavanja čustev ter spodbujanje pomoči vrstnikov ob jasni politiki šole glede MVN (Lee, Kim in Kim, 2015). Ob tem morajo biti programi procesno naravnani - aktivnosti se morajo izvajati kontinuirano v daljšem časovnem obdobju, hkrati pa je treba udeležencem omogočiti, da svoje novo naučene veščine tudi čim večkrat uporabijo v vsakodnevnih situacijah.

Čeprav so učinki programov za preprečevanje MVN pogosto skromni, je treba imeti v mislih širšo sliko - s preventivnimi programi namreč želimo v prvi vrsti spremeniti prepričanja vseh udeležencev. To sicer 
zahteva svoj čas, a z vztrajnostjo lahko na dolgi rok pričakujemo spremembe - najprej v vedenju posameznih udeležencev, nato pa tudi spremembe na ravni celotne šolske kulture neke šole.

\section{Literatura in viri}

Ang, R. P., in Goh, D. H. (2010) Cyberbullying among adolescents: The role of affective and cognitive empathy, and gender, Child Psychiatry \& Human Development 4I(4), str. 387-397.

Archer, J., in Coyne, S. M. (2005) An integrated review of indirect, relational and social agression, Personality and Social Psychology Review 9(3), str. 212-230.

Bandura, A. (1999) Moral disengagement in the perpetration of inhumanities, Personality and Social Psychology Review 3(3), str. 193-209.

Bauman, S., in Del Rio, A. (2006) Preservice teachers' responses to bullying scenarios: Comparing physical, verbal, and relational bullying, Journal of Educational Psychology 98(I), str. 219-231.

Benitez, J. L., in Justicia, F. (2006) Bullying: Description and analysis of the phenomenon. Granada: University of Granada.

Besag, V. (2006) Bullying among girls: frends or foes? School Psychology International 27 (5), str. 535-55I.

Bradshaw, C. P., Sawyer, A. L., in O'Brennan, L. M. (2007) Bullying and peer victimization at school: Perceptual differences between students and school staff, School psychology review 36(3), str. 36I-383.

Bronfenbrenner, U. (1979) The ecology of human development. Cambridge: Harvard University Press.

Carpenter, D., in Ferguson, C. J. (2009) Zakaj dekleta ustrahujejo druga dekleta? Pridobljeno 27.6.20I2 s http://www.netplaces.com/delaing-with-bullies/types-of-bullying/direct- bullying-versus-indirect-bullying. htm.

Cheng, Y. Y., Chen, L. M., Liu, K. S., in Chen, Y. L. (2011) Development and psychometric evaluation of the school bullying scales: A Rasch measurement approach, Educational and Psychological Measurement $7 \mathrm{I}(\mathrm{I})$, str. 200-216.

Cornell, D. G. (2012) The school climate bullying survey: Description and research summary. Pridobljeno 19.5.2014 s: http://curry.virginia.edu/ uploads/resourceLibrary/School_Climate_Bullying_Survey_ Description_for_Distribution_5-22-I2.pdf

Craig, K., Bell, D., in Leschied, A. (2011) Pre-service Teachers' Knowledge and Attitudes Regarding School-Based Bullying. Canadian Journal of Education 34(2), str. 21-33. 
Crapanzano, A. M., Frick, P. J., Childs, K., in Terranova, A. M. (201I) Gender differences in the assessment, stability, and correlates to bullying roles in middle school children, Behavioral Sciences \& the Law 29(5), str. 677-694.

Darley, J. M., in Latané, B. (1968) Bystander intervention in emergencies: Diffusion of responsibility, Journal of personality and social psychology $8(4)$, str. $377-383$.

Dekleva, B. (1996) Nasilje med vrstniki v šoli in v zvezi s šolo. Ljubljana: Institut za kriminologijo pri Pravni fakulteti.

Demaray, M. K., in Malecki, C. K. (2003) Perceptions of the frequency and importance of social support by students classified as victims, bullies, and bully/victims in an urban middle school, School Psychology Review 32(3), str. 47I-490.

Doll, B., Song, S., in Siemens, E. (2004) Classroom ecologies that support or discourage bullying. V: D.L. Espelage in S.W. Swearer [ur.], Bullying in American schools: A social-ecological perspective on prevention and intervention. Mahwah, NJ: Erlbaum.

Doupona Horvat, M. (20II) Poročilo PIRLS 20ı. Ljubljana: Pedagoški institut. Dostopno na spletni strani: https://www.pei.si/vstopna-stran/ mednarodne-raziskave/pirls/pirls-2ori/

Doupona, M. (2016) Mednarodna raziskava bralne pismenosti PIRLS 2016. Povzetek rezultatov raziskave. Ljubljana: Pedagoški institut. Pridobljeno I 4.2.2019 s http://novice.pei.si/wp-content/uploads/sites/2/2017/12/PIRLS_povzetek.pdf

Eccles, J. S., Wigfield, A., in Schiefle, U. (1998) Motivation to succeed. V: Eisenberg, N. [ur.], Handbook of child psychology. Vol 3. Social, emotional and personality development. New York: Wiley.

Ellis, A. A., in Shute, R. (2007) Teacher responses to bullying in relation to moral orientation and seriousness of bullying, British Journal of Educational Psychology 77(3), str. 649-663.

Espelage, D. L., Mebane, S. E., in Adams, R. S. (2004) Empathy, caring, and bullying: Toward an understanding of complex associations. V: D.E. Espelage in S.W. Swearer [ur.], Bullying in American schools: A social-ecological perspective on prevention and intervention. Mahwah, NJ: Erlbaum.

Gofin R., Palti H., in Gordon L. (2002) Bullying in Jerusalem schools: victims and perpetrators, Public Health I16(3), str. 173-178.

Gregory, A., in Cornell, D. (2009) “Tolerating” adolescent needs: Moving beyond zero tolerance policies in high school, Theory into practice $48(2)$, str. $106-\mathrm{II} 3$. 
Gregory, A., Cornell, D., Fan, X., Sheras, P., Shih T., in Huang, F. L. (2010) Authoritative school discipline: High school practices associated with lower bullying and victimization, Journal of Educational Psychology IO2(2), str. 483-496. DOI: 10.1037/a0018562.

Holt, M., in Keyes, M. (2004). Teachers' attitudes toward bullying. V: D.E. Espelage in S. W. Swearer [ur.], Bullying in American schools: A social-ecological perspective on prevention and intervention. Mahwah, NJ: Erlbaum.

Jakin, S. (2013) Vloga nadarjenih učencev v medvrstniškem nasilju. Neobjavljeno diplomsko delo. Ljubljana: Filozofska fakulteta.

Kebler, D. (2016) Stališča dijakov do fazaniranja v povezavi z njihovimi izkušnjami. Neobjavljeno diplomsko delo. Ljubljana: Filozofska fakulteta.

Kochenderfer-Ladd, B., in Pelletier, M. E. (2008) Teachers' views and beliefs about bullying: Influences on classroom management strategies and students' coping with peer victimization, Journal of school psychology $46(4)$, str. $43 \mathrm{I}-453$.

Lee, S., Kim, C. J., in Kim, D. H. (2015) A meta-analysis of the effect of school-based anti-bullying programs, Journal of child health care i9(2), str. 136-I53.

Lundeen, R. (2013). Hazing, rituals of bondage. Charleston, SC: Create Space.

Marsh. H. W., Nagengast, B., Morin, A. J. S., Parada, R. H., Craven, R. G., in Hamilton, L. R. (20II) Construct validity of the multidimensional structure of bullying and victimization: An application of exploratopry structural equation modeling, Journal of Educational Psychology IO3(3), str. 70I-732.

Nansel, T. R., Overpeck, M., Pilla, R. S., Ruan, W. J., Simons-Morton, B., in Scheidt, P. (200I) Bullying behaviors among US youth: prevalence and association with psychosocial adjustment, JAMA 285(I6), str. 2094-2100.

Nishina, A., in Juvonen, J. (2005) Daily reports of witnessing and experiencing peer harassment in middle school, Child development $76(2)$, str. $435-450$.

Olweus, D. (1973) Personality and aggression. V: J.K. Coie in D.D. Jensen [ur.], Nebraska symposium on motivation, 1972. Lincoln: University of Nebraska Press.

Olweus, D. (1978) Aggression in the schools: bullies and whipping boys. Washingon, DC: Hemisphere. 
Olweus, D. (1993) Victimization by peers: Antecendents and long-term outcomes. V: K.H. Rubin in J.B. Asendorpf [ur.], Social withdrawal, inhibition, and shyness in childhood. Hillsdale, NJ: LEA.

Olweus, D. (1995) Trpinčenje med učenci, kaj vemo in kaj labko naredimo. Ljubljana: Zavod RS za šolstvo.

O'Neill, S. (2008) Bullying by tween and teen girls: A Literature, policy and resource review. Toronto: Kookaburra Consulting.

Parada, R. (2000) Adolescent Peer Relations Instrument: A theoretical and empirical basis for the measurement of participant roles in bullying and victimisation of adolescence: An interim test manual and a research monograph: A test manual. Publication Unit, Self-concept Enhancement and Learning Facilitation (SELF) Research Centre, University of Western Sydney.

Pečjak, S. (2015) Medvrstniško nasilje v šoli. Ljubljana: Filozofska fakulteta.

Pečjak, S., in Pirc, T. (2014) Sem opazovalec medvrstniškega nasilja: kaj lahko naredim? Pedagoška obzorja 29(I), str. 155-168.

Pečjak, S., in Pirc, T. (2015) Predictors and Forms of Intervention in Peer Bullying: Pre-service Teachers vs. Teachers, New Educational Review 39(I), str. 264-276.

Pečjak, S., in Pirc, T. (2017) Bullying and perceived school climate: Victims' and bullies' perspective, Studia psychologica 59(I), str. 22-33.

Pečjak, S., in Pirc, T. (2019) Unofficial hazing in secondary schools: Prevalence, activities, and attitudes, Psychology in the Schools 56(2), str. 194-205.

Pellegrini, A. D. (2002) Bullying, Victimization, and Sexual Harassment During the Transition to Middle School, Educational Psychologist 37(3), str. I5I-163.

Pepler, D. J., in Craig, W. M. (1995) A peek behind the fence: Naturalistic observations of aggressive children with remote audiovisual recording, Developmental Psychology 3I(4), str. 548-553.

Pergolizzi, F., Richmond, D., Macario, S., Gan, Z., Richmond, C., in Macario, E. (2009) Bullying in middle schools: Results from a four-school survey, Journal of School Violence 8(3), str. 264-279.

Polak, A., Smrtnik Vitulić, H., in Vošnjak, Š. (20II) Doživljanje različnih vlog v situacijah vrstniškega nasilja, Socialna pedagogika I5(3), str. 205-222.

Pozzoli, T., Ang, R. P., in Gini, G. (2012) Bystanders' reactions to bullying: A cross-cultural analysis of personal correlates among Italian and Singaporean students, Social Development 2I(4), str. 686-703. 
Pušnik, M. (1999) Vrstniško nasilje v šoli. Ljubljana: Zavod RS za šolstvo.

Rigby, K., in Johnson, B. (2006) Expressed readiness of Australian schoolchildren to act as bystanders in support of children who are being bullied, Educational psychology 26(3), str. 425-440.

Sanders, C. E., in Phye, G. D. (2004) Bullying: Implications for classroom. London: Elsevier Academic Press.

Sapouna, M. (2008). Bullying in Greek Primary and Secondary Schools, School Psychology International 29(2), str. 199-213. doi: https://doi. org/10.1177/0143034308090060.

Schäfer, M., Korn, S., Brodbeck, F. C., Wolke, D., in Schulz, H. (2005) Bullying roles in changing context: The stability of victim and bully roles from primary to secondary school, International Journal of Behaviour Development 29(4), str. 223-335.

Seals, D., in Young, J. (2003) Bullying and Victimization: Prevalence and Relationship to Gender, Grade Level, Ethnicity, Self-Esteem, and Depression, Adolescence 38(152), str. 735-747.

Simmons, R. G., in Blyth, D. A. (1987) Moving into adolescence: The impact of pubertal change and school context. Hawthorn, NJ: Aldine de Gruyter.

Smith, P. K., Ananiadou, K., in Cowie, H. (2003) Intervention to reduce school bullying, Canadian Journal of Psychiatry 48(9), str. 295-303.

Smith, P. K., Madsen, K., in Moody, J. (1999) What couses the age decline in reports of being bullied at school? Towards a developmental analysis of risk of being bullied, Educational Research 4I(3), str. 267-285.

Smith, P. K., Talamelli, L., Cowie, H., Naylor, P., in Chauhan, P. (2004a) Profiles of non-victims, escaped victimis, continuing victims, and new victims in school bullying, British Journal of Educational Psychology 74(4), str. 565-58I.

Smith, J. D., Schneider, B. H., Smith, P. K., in Ananiadou, K. (2004b) The effectiveness of whole-school antibullying programs: A synthesis of evaluation research, School psychology review 33(4), str. 547-56I.

Solberg, M., in Olweus, D. (2003) Prevalence estimation of school bullying with the Olweus Bully/Victim Questionnaire, Agressive Behaviour 29(3), str. 239-268.

Sullivan, K. (20II). The anti-bullying handbook. London: Oxford University Press.

Totura, C. M. W., MacKinnon-Lewis, C., Gesten, E. L., Gadd, R., Divine, K. P., Dunham, S., in Kamboukos, D. (2009) Bullying and victimization among boys and girls in middle school: The influence of perceived 
family and school contexts, The Journal of Early Adolescence 29(4), str. 57I-609. doi: http://dx.doi.org/10.1177/0272431608324190.

Troop, W. P., in Ladd, G. W. (2002) Teachers' beliefs regarding peer victimization and their intervention practices. In: Poster presented at the Conference on Human Development, Charlotte, NC.

UNESCO (2017) School violence and bullying. Global report. Pariz: UNESCO.

UNICEF (2OI4) Hidden in plain sight: A statistical analysis of violence against children. eSocialSciences.

Ttofi, M. M., in Farrington, D. P. (2011) Effectiveness of school-based programs to reduce bullying: A systematic and meta-analytic review, Journal of Experimental Criminology 7(I), str. 27-56.

Vernberg, E. M., in Gamm, B. K. (2003) Resistance to violence prevention interventions in schools: Barriers and solutions, Journal of Applied Psychoanalytic Studies 5(2), str. 125-138.

Vreeman, R. C., in Carroll, A. E. (2007) A systematic review of school-based interventions to prevent bullying, Archives of pediatrics \& adolescent medicine $16 \mathrm{I}(\mathrm{I})$, str. $78-88$.

Whitney, I., in Smith, P. K. (1993) A survey of the nature and extent of bullying in junior/middle and secondary schools, Educational research 35(I), str. 3-25.

WHO - World Health Organization (2004) School Mobbing: Bullying and Violence Against Children. Pridobljeno 9.7.201 I s http://www.acosoescolar.com/inicio/inicio.html

Yoon, J. S. (2004) Predicting teacher interventions in bullying situations, Education and Treatment of Children 27(12), str. 37-45.

Yoon, J. S., in Kerber, K. (2003) Bullying: Elementary teachers' attitudes and intervention strategies, Research in Education 69(I), str. 27-35. 